Marquette University

e-Publications@Marquette

College of Communication Faculty Research and

Publications

Communication, College of

$6-1-2008$

\title{
The Legitimacy and Moral Authority of the National News Council (USA)
}

Erik Ugland

Marquette University, erik.ugland@mu.edu

Accepted version. Journalism: Theory, Practice \& Criticism, Vol. 9, No. 3 (June 2008): 285-308. DOI. (C) 2008 SAGE Publications. Used with permission. 


\title{
The Legitimacy and Moral Authority of the National News Council (USA)
}

\author{
Erik Ugland \\ J. William and Mary Diederich College of Communication, \\ Marquette University \\ Milwaukee, WI
}

\section{Abstract:}

As an institution designed to resolve disputes between the public and the American news media and to assess the ethical standards of the mainstream media, the National News Council (1973-84) was, at least in the USA, a ground-breaking institution. This study suggests, however, that the Council's work was anything but revolutionary, and that it probably did more to entrench the received tenets of American journalism than to either validate or refashion them. By applying a conventional set of ethical standards in its resolution of disputes, by repeatedly emphasizing the First Amendment rights of the media respondents, by violating its by-laws and allowing the media members of the Council to dominate its membership, and by ruling in the vast majority of cases against the public complainants, the Council's work provides grist for those who might question its legitimacy and its value as a model of authentic press-public collaboration.

As long as there have been journalists, there have been disquieted citizen-critics seeking to hold them accountable -some lobbying for censorship or other government restraints and others promoting voluntary remedies: ethics codes, ombudsmen, journalism reviews. One of the most contentious suggestions in the United States has been the establishment of news councils -nongovernmental 
associations of journalists and non-journalists who hear, assess and resolve public complaints against the news media.

The Commission on Freedom of the Press (Hutchins Commission) recommended the creation of news councils in $1947,{ }^{1}$ but it was not until the late 1960s and early 1970s, amid a spate of attacks against the mainstream news media, ${ }^{2}$ that the first councils were founded in the United States. News councils have operated with some success in Canada, Australia and the United Kingdom, among many other countries (see Bertrand, 2002), but they have a mixed record in the United States where only three news councils remain in operation: the Minnesota News Council (formerly the Minnesota Press Council), established in 1971, the Washington News Council, established in 1998, and the Honolulu Community Media Council, established in 1970. Several others have been launched over the past half century but all have disbanded for one reason or another. ${ }^{3}$ Certainly the most prominent of these was the National News Council (hereinafter NNC or Council), which operated from 1973 to 1984, and which was the only attempt to employ this model on a national scale.

The NNC's dual mission was to 'receive, examine, and report on complaints concerning the accuracy and fairness of news reporting [and to] study and to report on issues involving freedom of the press' (Twentieth Century Fund, 1973: 3). As innocuous as this might have sounded to members of the public, it agitated a number of journalists who saw the first of these two mandates as an affront to their autonomy and a step toward regulation. Nevertheless, despite some strident opposition and a boycott by the New York Times, the NNC was launched on 1 August 1973. Over the next 11 years, the Council responded to hundreds of disputes between the public and the national news media, issued written opinions in 227 cases and published special reports on several legal and ethical dilemmas. Despite these efforts, the Council never established a place in the public's consciousness. Its members and staff worked in relative obscurity and its dissolution in 1984 received only a flicker of media coverage.

Two decades later, the American news media face a set of challenges at least as weighty as those of the early 1970s: a proliferation of scandals, ${ }^{4}$ the emergence of alternative media, the loss of readers and viewers (see Journalism.org, 2007) and the 
deterioration of public confidence in their work (Pew Research Center, 2007). This is a critical moment for journalism, and particularly for the more mainstream news media, which are struggling to distinguish themselves from the new cohort of bloggers and other do-ityourselfers and to retain the loyalties of their increasingly fickle and distracted audiences. Although many traditional journalists insist that their work is fundamentally different from that of their neophyte competitors, the public is less convinced. One potential remedy, some say, is not only to elevate the mainstream media's journalistic standards and performance but to give the public a meaningful role in assessing and defining the ethical boundaries of the profession. Toward that end, several prominent journalists and scholars ${ }^{5}$ have called for the resurrection of the NNC, the creation of more state news councils, or both. And the Johns S. and James L. Knight Foundation recently awarded two $\$ 75,000$ grants to recipients in California and New England to support their efforts to establish two new state/regional councils. All of this has renewed debate about the utility and hazards of news councils and their viability in the face of some persistent media opposition.

The idea of giving the public a means by which to hold journalists accountable is no doubt appealing to those who claim to be neglected, betrayed or disenfranchised by the mainstream news media, but it is anathema to many journalists like former New York Times executive editor Joseph Lelyveld who said, 'we [journalists] don't want to be monitored by a lot of self-appointed people' (Jenkins, 1997: 39), and broadcast station manager John Lansing who said, more bluntly:

To hell with 15 'community leaders' and assorted colleagues sitting around a table voting 'yes' and 'no' on questions that are not black and white. It's the job of journalists to cover journalism. (Lansing, 1997: 7-8)

This ethos of autonomy pervades the profession and poses a substantial obstacle for anyone seeking to foster a more collectivist ethical environment. It also shapes the enduring belief among many journalists that news councils are biased against them. One broadcast CEO even compared the members of the NNC to 'a group of vigilantes' (Shaw, 1981). Despite reassurances from people like former 
Milwaukee Journal editor Sig Gissler that 'a press council's role is that of [educator] not inquisitor' (Norman and Robinson, 1981: 3), skepticism still runs deep.

The concern among journalists is understandable but is it warranted? This study reassesses the work of the NNC, focusing on the written opinions ${ }^{6}$ it issued in its resolution of cases, and considers what they reveal about the Council, its institutional integrity and its value as a model for new efforts to achieve a public-press rapprochement. This study is concerned with the outcomes of the NNC's rulings (including the voting patterns of the Council and its individual members), the processes by which it adjudicated complaints (including both the rigor with which the Council followed its by-laws and the evidentiary thresholds it applied) and its rationales (including the standards it relied upon and the scope of its inquiries).

This study finds that:

1. there is little evidence to support the most persistent critiques of the NNC namely, that it was simply an extra-legal mechanism for punishing the press, particularly the elite national media;

2. there were measurable differences in the voting patterns of public and media members ${ }^{7}$ (although the extent of those differences might have been blunted by the procedural and substantive issues described herein);

3. the Council routinely violated its by-laws by allowing media members to outnumber public members;

4. the Council established a high burden for public complainants to meet in terms of both the evidence and the gravity of the alleged violation;

5. the Council routinely highlighted the First Amendment rights of the media respondents in ways that were not germane to its ethics-based inquiries; and 
6. the Council applied a conventional set of ethical standards in its adjudication of complaints without articulating their justifying rationales or engaging in an examination of alternatives.

All of this flies in the face of the prevailing critique of the Council by members of the media and suggests that the Council's public constituents might have had a stronger basis for questioning its legitimacy as an honest arbitrator and its moral authority as an expositor of normative standards.

\section{The National News Council}

Despite the unyielding resistance of many journalists, the NNC was established in 1973 and operated continuously for more than a decade before running out of money -nearly all of which came from the Markel Foundation and the Twentieth Century Fund. ${ }^{8}$ Former Council President Norman Isaacs said later that the Council, in its continuing attempts to expand, 'essentially spent itself out of business' (1986: 131). But that was only its most immediate problem. More significant was the Council's inability to temper the persistent and vocal hostility of many journalists and to attract the public's attention (Brogan, 1985: 90-2). The members of the Council were certainly a distinguished group and included media members such as National Review publisher William Rusher, Oakland Tribune editor Robert Maynard, and Molly Ivins, then the editor of the Texas Observer, and public members such as Children's Television Workshop President Joan Ganz Cooney, retired Congresswoman Edith Green, and Derrick Bell, dean of the University of Oregon Law School. Still, the Council's members were not household names and whatever attention the organization received was probably attributable to factors other than the star-power of its participants.

The seeds of the NNC were planted in 1947 by the Hutchins Commission, which recommended the establishment of an independent body that could foster media accountability while avoiding the hazards of government restraints. The Council's real genesis, however, did not come until 1971 when the Twentieth Century Fund (TCF) sponsored a task force to explore the feasibility of a national news council. The project was initiated by TCF Director Murray $\mathrm{J}$. Rossant, a former journalist, and was undertaken at a time when both 
the credibility and freedoms of the press were under assault by the Nixon Administration and by other government and public critics. The task force -comprised of journalists like Richard Harwood of the Washington Post and John Oakes of the New York Times, and nonjournalists like Lucy Wilson Benson, then-head of the League of Women Voters - voted unanimously to recommend the establishment of a council. Several of the task force members, joined by the leaders of four foundations, then assembled a founding committee to write the Council's by-laws and select its members. Interestingly, there were only three journalists on the founding committee and eight nonjournalists, including the director, retired Judge Roger Traynor. This might help explain why the committee drafted by-laws that required the Council to be comprised of six media members and nine public members, with a chairman chosen from among the public members. As it turned out, however, the Council had several media members serve as chairman, and the public members were routinely outnumbered by their media counterparts. This was the central dilemma for the NNC: how to maintain its equilibrium while serving the interests of two distinct and often competing constituencies. It is a dilemma faced by other agents of media accountability as well, particularly news ombudsmen, who are perceived skeptically by both their audiences and their co-workers (Nelson and Starck, 1974) and who harbor differing beliefs about the group to whom they owe the greatest duty (Ettema and Glasser, 1987).

Although it was frequently buffeted by critics from both sides, the NNC survived for more than a decade, resolved hundreds of disputes, provided a voice of conscience in public debates over press freedom and responsibility and proved that most news organizations are in fact willing to submit to external scrutiny. As its books were being closed, NNC chairman and former CBS News president Richard Salant wrote what would be his farewell essay and the Council's epitaph: 'I refuse to believe that a concept so important and so sound as that which gave birth to the news council cannot be brought to reality. It is imperative that the effort be renewed and continued' (1983: xvii). A generation later, despite the conclusions of some that the Council was 'a spectacular failure' (Meyer, 1987: 168), some prominent journalists have repeated Salant's call for the resurrection of the NNC or some version of it. 
One of them is former 60 Minutes reporter Mike Wallace (1996) who said that most of those who oppose news councils are driven by unreasonable fears of regulation and a self-destructive hostility to criticism. In response to Wallace, former New York Times executive editor Joseph Lelyveld made clear his continued opposition. Mirroring criticisms offered by Times publisher Arthur Ochs Sulzberger in 1973 (see Brogan, 1985: 117-20), Lelyveld said news councils sacrifice press independence and help create an environment in which government regulation becomes more accepted. He added that the news council process itself could not be trusted. 'It's a kind of glorified town meeting. But it's not even a town. Talk about elitism! Who gets on these things, and the people who sit there, how hard do they work at it?' (Jenkins, 1997: 39). Former Life reporter Hillary Johnson, who was criticized in one of the NNC's rulings, called the Council a 'fatuous' and 'occasionally dangerous sham' (Brogan, 1985: 66). And broadcast station owner Stanley S. Hubbard offered a similar critique of the Minnesota News Council, saying it was akin to a 'kangaroo court' (St. Paul Pioneer Press, 1997).

Despite these criticisms, re-establishing a national news council is not just the peculiar interest of a restless minority. Walter Cronkite, who once opposed the NNC, has since said that he may have been wrong (Wallace, 1996), and Steve Geimann, former president of the Society of Professional Journalists, suggested that a news council might be a good way of defecting press criticism (Stein, 1997).

\section{Literature review}

Despite the attention news councils have received in the journalism trade press over the past three decades, relatively little research has been done on either the NNC or news councils generally. Many of the studies have addressed perceptions and attitudes of both journalists and members of the public about the value of councils. Polich (1974) surveyed publishers, editors and reporters and found that 53 percent either somewhat or strongly disapproved of councils, while 14 percent somewhat or strongly approved. Opposition to the NNC was weaker (two to one) than opposition to local press councils (four to one). Forty-five percent agreed that news councils were either a 'cosmetic device to cover media problems' or a 'club to intimidate the press', while only 30 percent viewed them as useful for addressing 
concerns about the news media. Whatever differences remain among journalists, the public appears to be less divided. In a survey by the Center for Media and Public Affairs (Shepard, 1997), 85 percent of the public respondents indicated they would support the use of news councils to investigate complaints against the news media.

Schafer (1979) examined media and complainant attitudes toward the Minnesota News Council (MNC) and found relatively high approval among both. Complainants were more approving than journalists, and among journalists, those working for daily newspapers were most supportive, followed by those at weekly papers and then those in radio and television. Although they were generally sympathetic to the news council concept, journalists were much more likely to view the procedures and determinations of the MNC as biased in favor of complainants than complainants were to view them as biased in favor of the media.

Cassady (1985) suggested that media opposition is primarily rooted in the First Amendment and the tradition of press autonomy that has prevailed in the USA. He argued that this tradition has fostered an intolerance on the part of journalists to public critiques of their work. A survey by Meyer (1987) found continued press opposition to news councils, but opposition was strongest among publishers and editors, as opposed to reporters, and significantly stronger among older journalists than younger.

Other research on news councils has focused on their effects. In a study of the impact of community press councils in two Illinois cities, Atwood and Starck (1972) found little change in the content of local newspapers after introduction of a community press council and also little change in public approval of those newspapers. Two years earlier, however, Starck (1970) found that some local press councils were having demonstrably positive effects on their communities by helping educate the public about journalistic standards.

There is some evidence that local councils have been more effective than the NNC in the eyes of complainants. Hermanson (1994) compared survey results of NNC and MNC complainants and found that MNC complainants tended to be less critical and more supportive of the process. In a doctoral dissertation, Husselbee (1999) used cluster 
analysis to try to identify linkages in the voting patterns of individual members of the NNC. He found no significant factions on the Council and no significant disparity in the treatment of particular news organizations, including the New York Times, which had been the most prominent and vocal critic of the NNC.

Of particular concern to both opponents of news councils and some proponents is the degree to which councils can help define ethical boundaries for journalism. In a study on the MNC, Schafer (1981) examined all of the Council's decisions and found that in several areas -access, accuracy and privacy -they provided significant ethical guidance. Although many see this as a useful role for councils, others say it raises the specter of council rulings being used to establish legal standards -something Farrar (1986) later warned against.

Precedent was also the focus of a study by Ugland and Breslin (2001) that examined all of the written opinions of the MNC. Their article looked at whether the MNC was consistent in applying its own precedents in subsequent rulings. They found that the MNC rarely cited its prior rulings and failed to articulate reasons for departing from them. They also found that in only about two-thirds of its decisions did the MNC justify its rulings by referencing or articulating clearly defined principles that could serve as guides to working journalists and benchmarks for future rulings.

\section{Conceptual framework and research questions}

The National News Council served two principal functions. The most immediate was to resolve disputes between the national news media and aggrieved readers, viewers and subjects. Toward that end, the Council operated as both an arbitrator, resolving disputes informally behind the scenes, and as a quasi-court - albeit one without enforcement powers ${ }^{9}$ - holding hearings and issuing formal written opinions on the most serious complaints. The less conspicuous but perhaps more important function of the Council was to apply and occasionally re-examine ethical standards and behavioral norms in journalism through a press-public collaboration. Brogan (1985: 39) says the Council's function was to 'consider matters of general journalistic principle and to promulgate rules to cover them'. In doing 
this, the Council would presumably refer to prevailing practices, but also critique, clarify and perhaps redefine them as well. (Indeed, if the goal had been merely to ratify and apply conventional journalistic standards, without any consideration of the merits of those standards, it would have been less important, if not completely unnecessary, to include public members on the Council.) In this way, the Council's rulings would help to shape professional practice by serving as normative guideposts for working journalists. As Council Chairman Stanley Fuld wrote in 1975: 'the National News Council is building its own record of performance', and 'evolving out of that record are a number of principles which, if observed by news organizations, could increase public confidence in their performance' (National News Council, 1975: 1-2).

In order for the Council to have this kind of influence, it needed to have moral authority. Moral authority, as defined here, is not a power that one possesses over another where defiance can lead to punishment or stigma. Nor is it 'that sense of authority which is derived from a perception of the individual or organization as having a superior competence to [your] own in certain matters, as a result of which [you are] willing voluntarily to accord them a measure of authority over [you]' (White, 1996: 66). It is, rather, the ability of councils -by virtue of the individual and collective credentials and judgments of their members, and by virtue of the impartial and deliberative processes through which they operate -to persuade their two key constituencies that their decisions and rationales are worthy not merely of attention but of adherence. Moral authority, then, is the power to 'substantially influence the decisions and behaviors of others by serving as a referent for their moral or ethical choices' (Ugland and Breslin, 2001: 234).

This study assumes that for any news council to have moral authority, it must be perceived as legitimate in the eyes of its constituents or stakeholders. Legitimacy is a wide-ranging concept employed differently in various disciplines, but it is used here to describe the accord that exists between the organization and its stakeholders over the organization's goals, structure and operation. For an organization to be legitimate, its stakeholders must be satisfied that it 'acts within the boundaries of the power conferred upon it , it acts in ways that advance the purposes for which it was created, and it 
follows its own publicly communicated procedures' (Ugland and Breslin, 2001: 234). Clearly any evidence of a systematic favoring of one group or set of interests would undermine the Council's legitimacy. This could be manifest through a bias on the part of the members or through a set of structural or practical forces.

In light of this, the first three research questions employed in this study look at questions of basic institutional integrity and fairness and are designed to provide some baseline data for assessing some of the key criticisms of the NNC and of news councils generally. The fourth question addresses a different aspect of legitimacy: specifically, whether the Council made an attempt through its written opinions to not only identify a principle or standard upon which its decisions rested, but to justify its value as an ethical marker. One of the central goals of the NNC was to seek solutions through an alliance of two distinct stakeholder groups. It was an opportunity, perhaps, to move past entrenched norms by providing a detached assessment not only of journalism's standards, but also its purposes. As several scholars have pointed out, ethics debates in journalism too often revolve around the sensational misdeeds of rogue reporters or individuals' violations of widely accepted professional conventions (Glasser, 1999). Rarely is there debate about the value of those conventions and whether respect for them is still warranted (Iggers, 1999). The collaborative model of the NNC, in which more of the affected parties were given a seat at the table, represented, at least potentially, an antidote to the insider approach that has predominated in the debates over journalism ethics, and which has largely kept non-practitioners on the periphery. So, to the extent that the Council merely applied a set of consecrated standards in its resolution of cases, its legitimacy could be questioned by those who were merely witnesses to it.

This study addressed the following questions:

RQ1: Do the Council's written opinions reveal disparities in the Council's treatment of particular parties (media respondents vs public complainants), particular organizations or particular media?

RQ2: Do the Council's written opinions reveal disparities in the voting patterns of public members vs media members? 
RQ3: Do the Council's written opinions suggest that the Council established clear adjudicative standards for its handling of complaints? Did the Council comply with those standards?

RQ4: Do the Council's written opinions reveal any efforts by the Council to identify principles or standards as the foundation for its rulings? If so, did the Council provide a justifying rationale for their application and/or an examination of alternatives?

\section{Method}

These questions were addressed through a quantitative and qualitative analysis of the Council's written opinions. To address the first three research questions, each opinion was reviewed to determine the success rate of public complainants and media respondents, to examine variations among different types of media respondents and to observe changes over time. Individual votes of Council members were also studied for all years except 1974 - the Council's first year of operation and one in which individual votes were not recorded. The composition of the Council was also tracked to determine whether there was an even split in the number of media versus public members present and voting in each case.

This study analyzed only those cases in which the Council issued a written opinion. Although case numbers were issued by the Council on 227 complaints, several of those were dismissed for procedural reasons. Because the Council did not issue written opinions in those cases and did not assess their substantive merits, they were not included in this study. If multiple votes were taken on the same complaint, each vote was treated as a separate complaint.

To address the fourth research question, each written opinion was read to determine whether the Council attempted to identify a standard upon which its decision rested and whether the Council engaged in any examination of the merits of those standards. The concurring and dissenting opinions were studied in the same way. This information was gathered to inform judgments about whether the Council served as an enforcer of traditional journalistic standards and whether it critically evaluated those standards. The aim was not 
NOT THE PUBLISHED VERSION; this is the author's final, peer-reviewed manuscript. The published version may be accessed by following the link in the citation at the bottom of the page.

primarily to quantify the findings but to provide a sense of the opinions and an understanding of their essential character.

\section{Findings and discussion}

After analyzing all of the written opinions issued by the NNC, there is little evidence that the Council was, as some of its media critics suggest, insensitive to the interests of journalists and media organizations. Table 1 and Figure 1 show that media respondents had a higher - and usually much higher - success rate than did public complainants. This was true in all years except 1980 and 1983 . Of the 196 determinations, ${ }^{10}$ media respondents won 124 (63.3\%), lost 54 $(27.5 \%)$ and split $18(9.2 \%)$. Table 1 also shows a decline in the media's success rate between the first and last years studied. Media respondents won 85 percent of the cases in 1974 and just 36 percent in 1983. The decline in the media's winning percentage began after 1977 but was even sharper after 1979. From 1974-9, media respondents won 72 percent of the time, but only 41 percent from 1980-3. There are several possible explanations. First, it could be that the Council, eager to earn the support of a skeptical, and at times hostile, journalistic community, was more sympathetic to respondents in the Council's early years. Second, it could be that there were fewer frivolous claims heard by the Council in the later years, which itself could be the result of increasingly thorough means of weeding out spurious complaints. ${ }^{11}$ Finally, it could be at least partly the result of the fact that the media members routinely outnumbered the public members on the Council - in contravention of the Council's by-laws and that this disparity was less pronounced in the Council's later years.

Table 1 appears to work against the suggestion that the Council was corrupted by an anti-media bias. If that claim were true, one would have to argue that the media respondents should have won an even higher proportion of the cases brought before the Council. That is certainly possible, but it seems less likely than the alternative, because complaints lacking credibility were dismissed or settled by the NNC's Grievance Committee and were not heard by the full Council. The Council's rulings, then, were based on the 'best of the best' complaints and had gone through several filters before reaching the full Council. On the surface, then, it would seem that a more credible argument

Journalism: Theory, Practice \& Criticism, Vol. 9, No. 3 (June 2008): pg. 285-308. DOI. This article is @ SAGE Publications and permission has been granted for this version to appear in e-Publications@Marquette. SAGE Publications does not grant permission for this article to be further copied/distributed or hosted elsewhere without the express permission from SAGE Publications. 
could be made that the Council was biased in favor of the media. Indeed, the analysis conducted in response to RQ3 and RQ4, described below, provides additional examples of the Council's procedural and substantive deference to media respondents. There is not enough evidence here to substantiate either the existence or absence of bias. But at the very least these results present an empirical hurdle that the most determined news council critics must surmount.

There is also little evidence to support the claim that the Council was antagonistic toward the interests of either particular media or organizations. Among all respondents, the broadcast networks fared best. CBS won 85 percent of the complaints brought against it (29 of 34) and $A B C$ won 94 percent (16 of 17). NBC had the worst record of the three broadcast networks but still won 57 percent of the time ( 8 of 14). The same was true of the other national news organizations. Even the New York Times, the Council's most committed critic, won twothirds of the time (14 wins, 6 losses, 1 split). This is especially noteworthy because by refusing to participate in the process, the Times never filed documents with the NNC to support its position.

Table 2 shows the respondents grouped by medium. The major wire services (AP and UPI) won two-thirds of their cases before the Council. Magazines fared the worst, winning 8, losing 14 and splitting 4. Part of the reason for this might be that several of the magazines against which complaints were brought were not traditional news magazines. They included Consumer Reports, Parade and Reader's Digest. Time magazine was more successful, winning three times, losing once and splitting once. Newsweek lost both of the complaints brought against it. Perhaps not surprisingly, tabloids did not do well. Six of the eight cases involving tabloids (New York Post, New York Daily News, National Inquirer) were decided in favor of the complainant. Aside from the poor success of magazine respondents, television, newspapers and wire services all won most of the time. When combining the success rates of all the major national news organizations (New York Times, Wall Street Journal, Washington Post, Chicago Tribune, ABC, NBC, CBS, AP, UPI, Time and Newsweek), media respondents won 70 percent of the time (83 wins, 23 losses and 13 splits). This belies the accusation that the Council's aim was to attack the 'establishment press', and given the success of most of the individual media organizations in that group, there is no clear support and permission has been granted for this version to appear in e-Publications@Marquette. SAGE Publications does not grant permission for this article to be further copied/distributed or hosted elsewhere without the express permission from SAGE Publications. 
for the charge that particular news organizations, not least of which being the New York Times, were targeted for unfavorable treatment. In fact, the results, at least on the surface, seem more supportive of the suggestion that the Council was especially protective of media respondents, although it would be too much to conclude that it was biased.

With respect to the second research question, which addressed differences in the voting patterns of public versus media members, it was clear that there were some differences between the two groups. The media members were more likely to favor media respondents than were public members, for example. Conversely, as Table 3 indicates, public members tended to favor public complainants more than the media members did. Both groups voted more often for the media respondents, but the media members did so 61 percent of the time while the public members did so only 55 percent of the time. Similarly, public members voted in favor of public complainants 34 percent of the time while the media members voted in favor of public complainants 31 percent of the time. The results indicate that there were significant differences in the voting patterns of the two groups and that group membership was somewhat predictive of a voting tendency. Nevertheless, the differences are not so stark as to suggest that the public and media members were working from completely different frameworks. The trajectories of the two groups' decisions track relatively closely, even though they can be differentiated. Some people, particularly the media critics of the Council, might have assumed there would be an even wider disparity in the voting tendencies of the two groups. One explanation might be that the two groups' conceptions of professional ethics are in fact largely overlapping. Another possible explanation, discussed more below, is that because the media members always outnumbered their public counterparts, and because the Council applied a more or less conventional set of professional standards in reaching its decisions, the public members might have had a weaker voice in the Council's meetings and less opportunity to explore less orthodox approaches.

When looking at the voting patterns of individual Council members, one can find broad disparities between those on the extremes. For example, media members Ivans, Strauss and Dilliard each voted in favor of the media respondent about 80 percent of the 
time, while public members Woolf, Height, D. Bell and J. Bell were each closer to 50 percent, and a few -Maynard, Barrett and Miller cast a majority of their votes against the media respondents. But much of this variation is attributable to the period in which these members served on the Council (recall that the media winning percentage was much higher in the Council's early years). Perhaps more revealing are the differences in the patterns of the members' dissenting votes. Out of all the dissenting votes cast, there was a relatively even split between support for the media respondent ( 51 votes) and the public complainant (45 votes). These numbers parallel the overall winning percentage for media respondents versus public complainants. However, exactly two-thirds of the media members' dissenting votes were in favor of the media respondent compared to only about onethird (36\%) of the public member's dissenting votes. Conversely, about two-thirds (64\%) of the public members' dissenting votes were in favor of the public complainant compared to exactly one-third of the media members' dissenting votes. This suggests that, at least among those who cast dissenting votes, there was a noticeable media-public divide, with members being more sympathetic to the parties with whom they had the most in common. This division might not be a bad thing. Perhaps it simply reinforces the Council's starting assumption that, as former NNC Chairman Norman E. Isaacs put it, 'something useful and broadening comes out of the blending of professional and public viewpoints' (1979: 1). Clearly, the members of the Council did not march in lock step. Nevertheless, there is a great deal of congruity in their opinions, most of which were unanimous. It is worth considering whether that congruity might have been shaped by other factors.

The first two research questions addressed patterns or irregularities in the votes of the Council or its members. The third research question asks whether any of these patterns can be explained by something other than the judgments and penchants of Council members. The defining attribute of the NNC was that it was to be a partnership between two distinct constituencies. To guard against media domination, the Council's original by-laws required that membership be set at 15 , with nine public and six media members (National News Council, 1979: 149). This was later changed to 18 total members with 10 public members and eight media members (National 
NOT THE PUBLISHED VERSION; this is the author's final, peer-reviewed manuscript. The published version may be accessed by following the link in the citation at the bottom of the page.

News Council, 1979: 427). Media members were never supposed to be in the majority.

This was the design but not the reality. Between 1974 and 1979 -a period in which the media respondents won 72 percent of all cases - the media members present and voting had a mean majority of +3.13 over their public counterparts. In other words, on average, there were more than three more media members present and voting than public members. ${ }^{12}$ In the period between 1980 and 1983, however, when the media won only 50 percent of their cases, their average majority was only +1.35 . From 1974 to 1979 , the media members held a majority 93 times and the public members only five. From 1980 to 1983 , the media members were in the majority 37 times and the public 13 times. Table 4 shows the average media majority for each year, excluding 1974 during which data on individual votes were not recorded.

In all years, the media members were in the majority 130 times, public members 18 times. As Table 4 shows, the media had a mean majority of at least +2.00 for all but one year, 1983. In 1978 and 1979, the Council had an average of more than four more media members than public members, and in some of the cases decided by the Council during those years, the media members had a majority of as many as +8 . It is also worth noting that the chairman of the NNC was in all but the first two years a media member, even though the Council's by-laws required that the chairman be a public member (National News Council, 1979: 429).

These data show that the success of media respondents could have been at least partly structural, with the Council's media members routinely holding strong majorities. Because media members voted in favor of respondents at a higher rate than did public members, and because media members dominated the Council in terms of their numbers present and voting, media respondents had some advantage. This also helps explain - albeit only partially - why the success of media respondents was lower in the last few years of the Council's operation.

The other significant procedural obstacle faced by complainants was that the Council never established clear burden-of-proof standards and permission has been granted for this version to appear in e-Publications@Marquette. SAGE Publications does not grant permission for this article to be further copied/distributed or hosted elsewhere without the express permission from SAGE Publications. 
or criteria by which to determine whether a complaint was warranted or unwarranted. Decisions appear to have been made ad hoc. After analyzing all of the Council's written determinations, it is clear that the Council was largely deferential to the media respondents and was unwilling in most cases, particularly in the years prior to 1980 , to find complaints to be warranted in the absence of clear and substantial evidence of significant errors or ethical missteps. Media respondents were afforded a strong presumption of innocence, so to speak. The Council frequently found complaints unwarranted even after identifying significant failures on the part of the respondents. In one case, for example, the Council criticized a newspaper for covering several political candidates' press conferences without doing the same for the incumbent. Still, the Council found the complaint unwarranted, noting that the paper probably should have reported on the conference, but that its 'decision not to do so was within the range of the paper's editorial discretion' (National News Council, 1979: 110). In another case, the Council criticized ABC's selective editing of a statement from Rev. Billy Graham that made it appear that Graham was condemning President Richard Nixon even though the full statement reaffirmed their friendship. The Council found the complaint unwarranted, holding that 'ABC was under no obligation to air the entire [statement]' (National News Council, 1975: 106). These are just a couple of examples but they are representative of the Council's common tendencies. One was to immunize respondents with respect to matters of 'editorial discretion'. The Council, quite legitimately, did not want to substitute its judgments for those of journalists over minor matters of style or assessments of newsworthiness. But the Council took this to an extreme. When one news organization published false and incriminating information from a mistranslated foreign source, for example, the Council concluded that the organization's refusal to publish a correction was 'a matter of editorial judgment [that] rests with the news organization' (National News Council, 1979: 33).

Another tendency of the Council was to make reference to the First Amendment and the rights of media respondents even though its inquiries were, by rule, confined to questions of ethics. The Council held in one case, for example, that to criticize ABC's reporters for injecting their own commentary into their reports would be 'a denial of [the reporters'] rights to express their own opinions' (National News Council, 1975: 135). It added in a subsequent decision that it has 
'consistently upheld the right of journalists to expression of opinion' (National News Council, 1979: 105). And in another case it said a broadcaster's decision about whether to provide instant analysis of speeches and other news events was 'within the area of editorial judgment and, in accordance with First Amendment principle, it's properly determined by the broadcasters' (National News Council, 1975: 78). The Council also made a number of less direct references to law, noting, for example, that a respondent was 'well within its rights' (National News Council, 1979: 48), 'well within the protection of the First Amendment' (National News Council, 1984: 170), or 'well within the bounds of permissible journalistic practice' (emphasis added) (National News Council, 1984: 171), even though the Council had no authority to resolve legal issues, nor were the standards from that domain relevant in the news council context. The Council also made indefinite references to 'obligations', writing on several occasions that a respondent was under 'no obligation' to provide more balance in its stories, even though it might have been helpful. The Council was never clear whether it was referring to ethical obligations or legal ones, which, along with all of these other references, could have reinforced the suspicions of some that the Council's inquiries were shaped as much by the permissive standards of law as they were by the more exacting, virtue-based standards of ethics.

The Council's references to law and the First Amendment were almost always irrelevant to, and even incompatible with, its immediate tasks and are suggestive of a pro-media disposition. One can only speculate about the Council's motivations, but in light of the persistent criticism it faced from journalists - whose support the Council always struggled to maintain - and the enduring accusation that the Council's work undermined media autonomy and emboldened censors, it is not unlikely that the Council was especially wary of being perceived as a punisher. To the extent that the Council's First Amendment references were simply platitudinous attempts to reassure a skeptical constituency, they are not particularly remarkable. But looking at the totality of the Council's work, they seem part of a larger pattern of media solicitude that could have undermined the Council's legitimacy in the eyes of its public constituents. At the very least, these tendencies render less credible the claims of Council critics that it was little more than an officious overseer designed to reign in the press. 
The final research question addressed more substantive dimensions of the Council's work - specifically, whether it articulated normative standards for journalists and, more importantly, whether it buttressed them with justifying rationales and examinations of alternatives. If the Council was to be perceived as legitimate and to have the moral authority to shape professional practices, it had to be viewed as an honest arbiter whose judgments were the products of an interchange among co-equal members. It is impossible to know from the Council's written opinions the precise nature of the dialog among the members, but in the opinions themselves the Council applied a very conventional set of standards in its resolution of complaints - at least in those opinions in which a standard was discernible.

Although the NNC was designed to be both a settler of conflicts and an expositor of standards, its rulings and written opinions were directed almost exclusively at the former. To that extent, the Council missed an opportunity to advance its educative function and perhaps to persuade its non-media constituents that its vision of ethical journalism was one that could serve both the media's and the public's interests. Of its 200-plus written opinions, fewer than 20 percent contained anything akin to a statement of principle or elucidation of a standard. In those cases where a standard was articulated, it was usually presented concisely:

Broadcast stations should apply the same standards of accuracy to news promotions as to news stories themselves. (National News Council, 1979: 123)

It is of course necessary that . . . opinion advertising should clearly be identified as advertising. (p. 82)

So long as it does not alter the intent of the letter or is not otherwise unreasonable, [deleting portions of letters to the editor] is clearly a function of the editors. ( $p .173$ )

These kinds of statements were helpful, as far as they went, but they were uncommon and were almost never supported by foundational arguments supporting their adoption. Their value was presented as self-evident. Indeed, the Council frequently used language suggesting that both the standards and their rationales were already known and accepted. It routinely held that a respondent had and permission has been granted for this version to appear in e-Publications@Marquette. SAGE Publications does not grant permission for this article to be further copied/distributed or hosted elsewhere without the express permission from SAGE Publications. 
acted either consistently or inconsistently with 'traditional journalistic standards' (National News Council, 1979: 286), 'accepted journalistic standards' (National News Council, 1984: 346), or some similar phrase, without explaining what those standards were, how they had come to be accepted, or what justified their continued application.

It should be noted that the Council did issue special reports, outside the context of its adjudication of complaints, which contained some deeper analyses and more comprehensive guidance on professional practices (although the vast majority of these special reports were not addressed to ethical issues but to what the Council believed were threats to the First Amendment). And of course one has to acknowledge the practical problems faced by the Council in trying to distill the thoughts of 10 to 15 people into a concise and instructive summary opinion. Nevertheless, the Council's written opinions, as a whole, largely addressed the examination of factual conflicts and not the identification of standards or core values. In addition, its opinions were almost entirely built around mainstream conceptions of journalism ethics and did not reflect any kind of alternative thinking. The NNC, by its very existence, broke new ground in fostering at least some modicum of press-public cooperation and in seeking to hold autonomous media institutions accountable. But it was far from revolutionary and may have done as much to entrench journalism's received tenets as it did to either validate or refashion them.

All of this raises questions about the legitimacy of the Council as perceived by its public constituents and about the depth and authenticity of the Council's collaborative purposes. Because the Council gave its members the opportunity to dissent from the majority opinions and to write their own separate (concurring or dissenting) opinions, and because many public members took advantage of these opportunities to express their disagreements or clarify the rationales for their votes, no one could claim that the Council silenced alternative perspectives. But it is important to consider whether a more subtle process of cooptation occurred - one that may not even have been apparent to the members - that prevented the public voices from getting their fullest expression and that increased the success of the media respondents. To the extent that the Council's decisions were based on assessments of industry norms and 'standard operating procedures', it may have subtly disenfranchised the public members and permission has been granted for this version to appear in e-Publications@Marquette. SAGE Publications does not grant permission for this article to be further copied/distributed or hosted elsewhere without the express permission from SAGE Publications. 
and in a way defeated one of the Council's primary purposes and legitimizing features. (Of course, it is possible that during the Council's meetings, its discussions were more wide ranging, but one would still expect some of that to seep into the Council's opinions, or at least the concurring and dissenting opinions.)

If something truly broadening comes from the intermingling of media and public voices, why was the Council so fixated on industry norms? And why would public participation on the Council have even been necessary if the whole enterprise was merely about testing the degree to which journalists complied with mainstream standards whose intricacies were not explored and whose value was not questioned? It is not clear how the Council came to adopt this posture. Perhaps the media domination on the Council, in terms of the number of members present and voting, helped to push the debate in that direction. Perhaps the public members viewed these matters as being more in the realm of expertise of the media members whom they afforded some deference. Or perhaps it never occurred to the public members to push for less conventional inquiries. These are matters that must be addressed through future study. What this article suggests, however, is that the Council in fact did not devote much attention in its written opinions to underlying rationales or to examinations of alternative approaches. And to the extent that this broke faith with the expectations of the public stakeholders, and to the extent that it heightened the success of media respondents at the expense of public complainants, it is relevant to assessments of the Council's legitimacy and moral authority.

\section{Conclusion}

This assessment of the work of the National News Council does not resolve long-standing criticisms of the organization, but it does pose a challenge to many of their core assumptions. There is no evidence to suggest that the Council was hostile to media respondents, nor is there any evidence that particular media or organizations were targeted for unfavorable treatment. In addition, there were structural and procedural obstacles - the Council's reliance on traditional journalistic standards, its emphasis on the First Amendment rights of the respondents, its abandonment of the membership provisions of its by-laws, and its failure to explore less conventional normative 
approaches - that gave a pro-media cast to much of the Council's work. Although it would be too much to call it a bias, the Council did provide grist for its public constituents to challenge its legitimacy as a judicious mediator. And by consistently exalting the canonical principles of mainstream journalism, without exploring their enduring value, it may have weakened its standing as a moral authority in the world of professional ethics.

\section{Notes}

1. The Hutchins Commission, named after its chairman, University of Chicago President Robert M. Hutchins, was a privately organized committee formed to study the tension between news media performance and media freedom under the First Amendment. It was formed in 1942 and issued recommendations in its final report, A Free and Responsible Press (Commission on Freedom of the Press, 1947).

2. Some of the most pointed criticism came from President Richard Nixon and others in the Nixon White House. Vice President Spiro Agnew was particularly vocal and is famous for once deriding mainstream journalists as 'nattering nabobs of negativism' (Isaacs, 1986: 118).

3. See generally, Claude-Jean Bertrand, 2003.

4. Among them, the admissions by former New York Times reporter Jayson Blair and former USA Today reporter Jack Kelley of plagiarism and fabrication, and CBS News' reliance on flawed documents in its story questioning President George W. Bush's National Guard service.

5. Among those who have publicly called for the creation of news councils are Geneva Overholser, Hodding Carter, Bill Moyers and Mike Wallace.

6. Whenever the full Council held a hearing to assess a public complaint, it wrote a written opinion, much like a court opinion, in which it explained whether and why the complaint was warranted or unwarranted. Council members who disagreed with the ruling of the majority occasionally wrote dissenting or concurring opinions, which they signed.

7. The Council used the term 'public members' to refer to its members whose 'major work and reputation are now in fields other than the news media', and 'media members' to refer to its members who were 'associated with the news media' (National News Council, 1975: 149). 
NOT THE PUBLISHED VERSION; this is the author's final, peer-reviewed manuscript. The published version may be accessed by following the link in the citation at the bottom of the page.

8. The Twentieth Century Fund and the Markle Foundation were by far the NNC's most substantial contributors. All told, the TCF contributed more than $\$ 700,000$ and Markle more than $\$ 1$ million to the Council (Brogan, 1985: 121).

9. The Council did not have the authority to impose punishments on the media respondents, nor to compel a response from them. Its impact depended on publicity from both the media respondents, who, as part of their participation in the news council process, agreed to publicize the Council's rulings, and the non-party media, which the Council members hoped would alert readers and viewers about the Council's rulings and its other activities.

10. The previous reference to 227 determinations includes the complaints that the Council dismissed after consideration by the full Council. Only 196 of these determinations met the criteria for this study.

11. Complaints made to the NNC were not automatically scheduled for hearing by the full Council. Only after the Grievance Committee had reviewed the complaint, scrutinized its assertions, conducted a preliminary investigation and attempted to informally resolve the dispute were the complaints scheduled for hearing.

12. Note that the total number of Council members present and voting varied considerably, from as few as eight to as many as 18 , with an average for all years of about 12 .

\section{References}

Atwood, L. E. and K. Starck (1972) 'Effects of Community Press Councils: Real and Imagined', Journalism Quarterly 49(summer): 230-38.

Bertrand, C. J. (2002) 'World Press Councils: 2001', Media Ethics 12(2): 12.

Bertrand, C. J. (2003) 'Local Press Councils in the United States', ch. 9 in An Arsenal for Democracy: Media Accountability Systems. Cresskill, NJ: Hampton Press.

Brogan, P. (1985) Spiked: The Short Life and Death of the National News Council. New York: Twentieth Century Fund.

Cassady, D. (1985) 'Press Councils -Why Journalists Won't Cooperate', Newspaper Research Journal 5(4): 19-25.

Journalism: Theory, Practice \& Criticism, Vol. 9, No. 3 (June 2008): pg. 285-308. DOI. This article is @ SAGE Publications and permission has been granted for this version to appear in e-Publications@Marquette. SAGE Publications does not grant permission for this article to be further copied/distributed or hosted elsewhere without the express permission from SAGE Publications. 
NOT THE PUBLISHED VERSION; this is the author's final, peer-reviewed manuscript. The published version may be accessed by following the link in the citation at the bottom of the page.

Commission on Freedom of the Press (1947) A Free and Responsible Press. Chicago, IL: University of Chicago Press.

Ettema, J. S. and T. L. Glasser (1987) 'Public Accountability or Public Relations? Newspaper Ombudsmen Defne their Role', Journalism Quarterly 64(1): 3-12.

Farrar, R. (1986) 'News Councils and Libel Actions', Journalism Quarterly 63(3): 509-16.

Glasser, T. L. (1999) 'When a Reporter Makes up News, Journalists Label It a Breach of Ethics, So Why Not When the Entire Industry Ducks a Signifcant Story?', Grade the News at Stanford University, URL (consulted January 2008): http://www. stanford.edu/group/gradethenews/pages/glasser.htm

Hermanson, L. W. (1994) 'News Council Complainants: Who Are They and What Do They Want?', Journalism Quarterly 70(4): 947-70.

Husselbee, L. P. (1999) 'A Question of Accountability: An Analysis of Grievances Filed with the National News Council, 1973-1984', PhD Dissertation, Ohio University.

Iggers, J. (1999) Good News, Bad News: Journalism Ethics and the Public Interest. Boulder, $\mathrm{CO}$ : Westview Press.

Isaacs, N. E. (1979) 'Chairman's Foreword: A Personal View', in In The Public Interest II. New York: National News Council.

Isaacs, N. E. (1986) Untended Gates: The Mismanaged Press. New York: Columbia University Press.

Jenkins, E. (1997) 'News Councils: The Case For and Against', Columbia Journalism Review 35(6): 38-9.

Journalism.org (2007) 'The State of the News Media 2007', URL (consulted January 2008): http://www.stateofthenewsmedia.org

Lansing, J. (1997) 'Another Weapon for the Already-Powerful', The Masthead 49(fall): 7-8.

Meyer, P. (1987) Ethical Journalism: A Guide for Students, Practitioners and Consumers. New York: University Press of America.

Journalism: Theory, Practice \& Criticism, Vol. 9, No. 3 (June 2008): pg. 285-308. DOI. This article is C SAGE Publications and permission has been granted for this version to appear in e-Publications@Marquette. SAGE Publications does not grant permission for this article to be further copied/distributed or hosted elsewhere without the express permission from SAGE Publications. 
NOT THE PUBLISHED VERSION; this is the author's final, peer-reviewed manuscript. The published version may be accessed by following the link in the citation at the bottom of the page.

National News Council (1975) In the Public Interest: A Report by the National News Council, 1973-1975. New York: National News Council.

National News Council (1979) In the Public Interest II: A Report by the National News Council, 1975-1978. New York: National News Council.

National News Council (1984) In the Public Interest III: A Report by the National News Council, 1979-1983. New York: National News Council.

Nelson, D. R. and K. Starck (1974) 'The Newspaper Ombudsman as Viewed by the Rest of the Staff', Journalism Quarterly 51(3): 453-7.

Norman, J. M. and L. R. Robinson (1981) 'A News Council for Wisconsin? The Pros and Cons', RF Monographs. River-Falls, WI: University of Wisconsin-River Falls Press.

Pew Research Center for the People \& the Press (2007) 'Views of Press Performance and Values: 1987-2007', URL (consulted August 2007): http://pewresearch.org/pubs/ 564/internet-news-audience

Polich, J. E. (1974) 'Newspaper Support of Press Councils', Journalism Quarterly 51 (summer): 199-206.

Salant, R. S. (1983) 'President's Foreword: A Personal View', in In the Public Interest III. New York: National News Council.

Schafer, R. (1979) 'News Media and Complainant Attitudes toward the Minnesota Press Council', Journalism Quarterly 56(4): 744-52.

Schafer, R. (1981) 'The Minnesota News Council: Developing Standards for Press Ethics', Journalism Quarterly 58(3): 355-62.

Shaw, D. (1981) 'News Councils Attempt to Monitor Conduct of Media', Los Angeles Times, 24 September, p. A1.

Shepard, A. C. (1997) 'Going Public', American Journalism Review 19(April): 29.

Starck, K. (1970) 'What Community Press Councils Talk About', Journalism Quarterly 47(spring): 20-6.

Stein, M. L. (1997) 'Revive the News Council?', Editor and Publisher, 29 March, p. 8.

St. Paul Pioneer Press (1997) 'Spreading the News', 30 November, p. D2.

Journalism: Theory, Practice \& Criticism, Vol. 9, No. 3 (June 2008): pg. 285-308. DOI. This article is @ SAGE Publications and permission has been granted for this version to appear in e-Publications@Marquette. SAGE Publications does not grant permission for this article to be further copied/distributed or hosted elsewhere without the express permission from SAGE Publications. 
NOT THE PUBLISHED VERSION; this is the author's final, peer-reviewed manuscript. The published version may be accessed by following the link in the citation at the bottom of the page.

Twentieth Century Fund (1973) A Free and Responsive Press. New York: The Twentieth Century Fund.

Ugland, E. and J. Breslin (2001) 'Minnesota News Council: Principles, Precedent and Moral Authority', Journal of Mass Media Ethics 15(4): 232-47.

Wallace, M. (1996) '19th Annual Frank E. Gannett Lecture', Freedom Forum Media Studies Center, New York, 4 December.

White, S. R. (1996) Authority and Anglicanism. London: SCM Press.

\section{About the Authors}

Erik Ugland is an Assistant Professor in the J. William and Mary Diederich College of Communication at Marquette University where he teaches graduate and undergraduate courses in media law, ethics and policy. Dr Ugland earned his BA, MA, JD and PhD degrees from the University of Minnesota where he was twice a fellow at the Silha Center for the Study of Media Ethics and Law. Before returning to Minnesota for his doctoral work, Dr Ugland was a research associate at both the Media Studies Center at Columbia University and the Freedom Forum World Center in Arlington, VA. In 2005-6, he served as head of the Media Ethics Division of the Association for Education in journalism and Mass Communication.

Address: J. William and Mary Diederich College of Communication, Bo 1881, Marquette University, Milwaukee, WI 532011881, USA. [email: erik.ugland@mu.edu] 
NOT THE PUBLISHED VERSION; this is the author's final, peer-reviewed manuscript. The published version may be accessed by following the link in the citation at the bottom of the page.

\section{Appendix}

Table 1: Percent of determinations 'for media,' 'against media' and 'split' by year

\begin{tabular}{lccccc}
\hline Year & For & Against & Split & Total & $n$ \\
\hline & $\%$ & $\%$ & $\%$ & & \\
1974 & 85 & 15 & 0 & 100 & 27 \\
1975 & 76 & 24 & 0 & 100 & 21 \\
1976 & 84 & 16 & 0 & 100 & 25 \\
1977 & 58 & 23 & 19 & 100 & 26 \\
1978 & 63 & 30 & 7 & 100 & 27 \\
1979 & 64 & 36 & 0 & 100 & 14 \\
1980 & 33 & 58 & 8 & 100 & 12 \\
1981 & 54 & 38 & 8 & 100 & 13 \\
1982 & 41 & 24 & 35 & 100 & 17 \\
1983 & 36 & 43 & 21 & 100 & 14 \\
\hline
\end{tabular}

Table 2: Percent of council determinations 'for media,' 'against media' and 'split' by media type (all years)

\begin{tabular}{lccccc}
\hline Media type & For & Against & Split & Total & $n$ \\
\hline & $\%$ & $\%$ & $\%$ & & \\
Newspaper & 66 & 25 & 9 & 100 & 53 \\
Television & 74 & 19 & 7 & 100 & 77 \\
Wire services & 71 & 19 & 10 & 100 & 21 \\
Magazines & 31 & 54 & 15 & 100 & 26 \\
Individuals & 55 & 27 & 18 & 100 & 11 \\
Tabloids & 25 & 75 & 0 & 100 & 8 \\
\hline
\end{tabular}

Table 3: Percent of votes 'for media,' 'against media' and 'split' by media members versus public members

\begin{tabular}{lccccc}
\hline Media type & For & Against & Split & Total & $n$ \\
\hline & $\%$ & $\%$ & $\%$ & & \\
Media member & 61.0 & 30.7 & 8.3 & 100.0 & 1104 \\
Public member & 55.2 & 33.8 & 11.0 & 100.0 & 681 \\
\hline
\end{tabular}

$d f=2 ; x^{2}=6.84 ; p=0.0327 ; r^{2}=0.0619$

Journalism: Theory, Practice \& Criticism, Vol. 9, No. 3 (June 2008): pg. 285-308. DOI. This article is C SAGE Publications and permission has been granted for this version to appear in e-Publications@Marquette. SAGE Publications does not grant permission for this article to be further copied/distributed or hosted elsewhere without the express permission from SAGE Publications. 
NOT THE PUBLISHED VERSION; this is the author's final, peer-reviewed manuscript. The published version may be accessed by following the link in the citation at the bottom of the page.

Table 4: Average difference between media members present and voting and public members present and voting (by year) with percentage of pro-media (excluding splits)

\begin{tabular}{lccccccccc}
\hline & 1975 & 1976 & 1977 & 1978 & 1979 & 1980 & 1981 & 1982 & 1983 \\
\hline Average media majority & +2.14 & +2.68 & +2.32 & +4.48 & +4.21 & +2.75 & +2.08 & +2.18 & -1.35 \\
Percent pro-media votes & 76 & 84 & 71 & 68 & 64 & 36 & 58 & 64 & 45 \\
\hline
\end{tabular}

$d f=2 ; x^{2}=6.84 ; p=0.0327 ; r^{2}=0.0619$

Figure 1: Percent of determinations 'for media,' 'against media', and 'split' by year

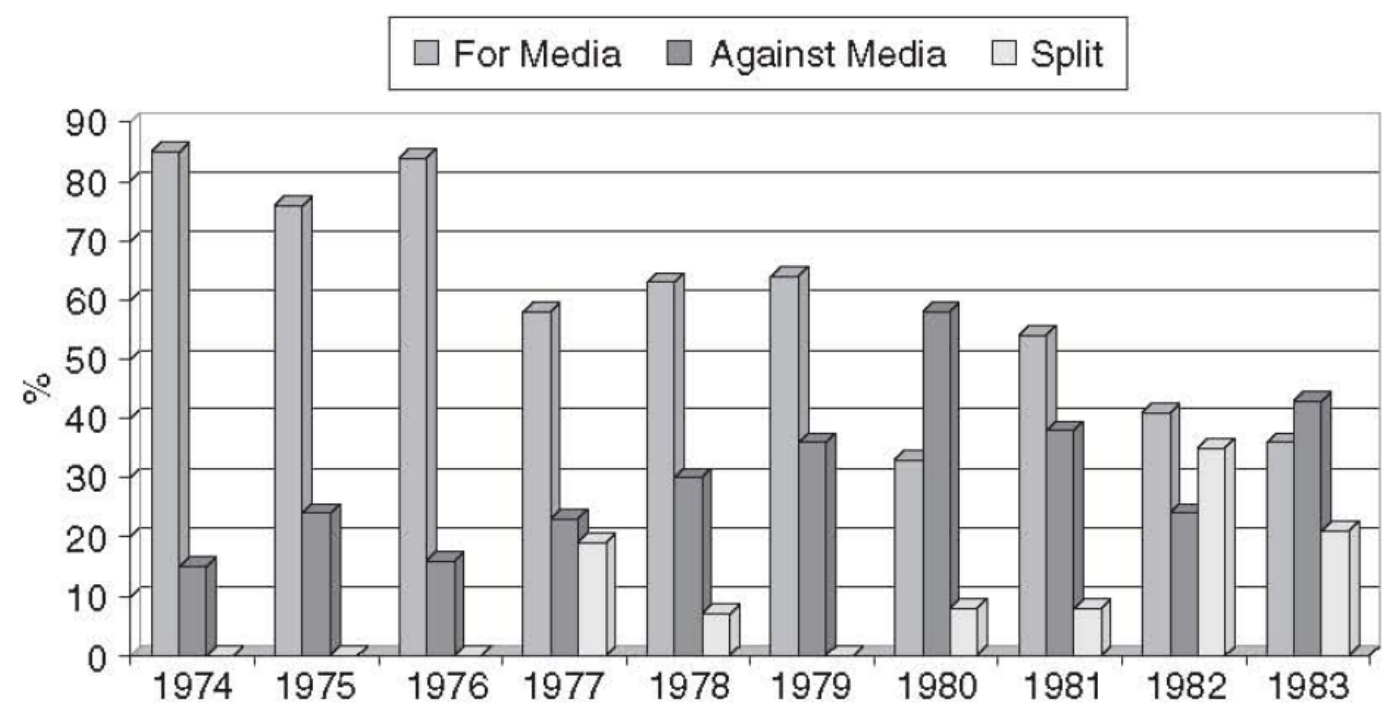

Journalism: Theory, Practice \& Criticism, Vol. 9, No. 3 (June 2008): pg. 285-308. DOI. This article is @ SAGE Publications and permission has been granted for this version to appear in e-Publications@Marquette. SAGE Publications does not grant permission for this article to be further copied/distributed or hosted elsewhere without the express permission from SAGE Publications. 